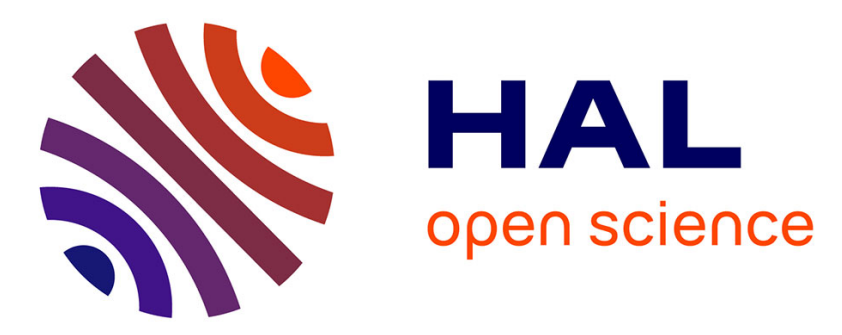

\title{
Effective Homogeneous Catalysis of Electrochemical Reduction of Nitrous Oxide to Dinitrogen at Rhenium Carbonyl Catalysts
}

Rana Deeba, Florian Molton, Sylvie Chardon-Noblat, Cyrille Costentin

\section{- To cite this version:}

Rana Deeba, Florian Molton, Sylvie Chardon-Noblat, Cyrille Costentin. Effective Homogeneous Catalysis of Electrochemical Reduction of Nitrous Oxide to Dinitrogen at Rhenium Carbonyl Catalysts. ACS Catalysis, 2021, 11 (10), pp.6099-6103. 10.1021/acscatal.1c01197 . hal-03380573

\section{HAL Id: hal-03380573 https://hal.science/hal-03380573}

Submitted on 3 Nov 2021

HAL is a multi-disciplinary open access archive for the deposit and dissemination of scientific research documents, whether they are published or not. The documents may come from teaching and research institutions in France or abroad, or from public or private research centers.
L'archive ouverte pluridisciplinaire HAL, est destinée au dépôt et à la diffusion de documents scientifiques de niveau recherche, publiés ou non, émanant des établissements d'enseignement et de recherche français ou étrangers, des laboratoires publics ou privés. 


\title{
Effective Homogeneous Catalysis of Electrochemical Reduction of Nitrous Oxide to Dinitrogen at Rhenium Carbonyl Catalysts.
}

\author{
Rana Deeba, ${ }^{a}$ Florian Molton, ${ }^{a}$ Sylvie Chardon-Noblat ${ }^{a, *}$ and Cyrille Costentin ${ }^{a, b, *}$ \\ ${ }^{a}$ Univ Grenoble Alpes, DCM, CNRS, 38000 Grenoble, France. ${ }^{b}$ Université de Paris, 75013 Paris, France. \\ Supporting Information
}

ABSTRACT: We show that reduced rhenium bipyridyl carbonyl complexes are stable and selective catalysts for deoxygenation of nitrous oxide $\left(\mathrm{N}_{2} \mathrm{O}\right)$ in organic media in the presence of water. Mechanistic studies indicate that the Re complex is initially reduced to produce the activated species. Then $\mathrm{N}_{2} \mathrm{O}$ binds to labile position at the reduced metal and the resulting adduct is further reduced to trigger $\mathrm{N}-\mathrm{O}$ bond breaking and release of $\mathrm{N}_{2}$. Proton donors are beneficial to enhance the catalytic rate and to reduce the energy required to generate potential limiting intermediate. These results open directions for N-O bond activation.

Keywords: $\mathrm{N}_{2} \mathrm{O}$, electrocatalysis, homogeneous catalysis, rhenium carbonyl, cyclic voltammetry, N-O bond activation.

Nitrous oxide $\left(\mathrm{N}_{2} \mathrm{O}\right)$ is a gas being part of the biological denitrification process transforming nitrates into dinitrogen. ${ }^{1}$ Its atmospheric concentration has increased in the last centuries due to extensive use of fertilizers and industrial processes. ${ }^{2}$ It is an unhappy situation because $\mathrm{N}_{2} \mathrm{O}$ is a greenhouse gas responsible for $4 \%$ of the additional greenhouse effect observed since the start of the industrial era. ${ }^{3}$ Moreover $\mathrm{N}_{2} \mathrm{O}$ is transformed by photolysis in the stratosphere into nitrogen oxides involved in the catalytic cycles of ozone destruction making $\mathrm{N}_{2} \mathrm{O}$ the main contributor to the destruction of the ozone layer of the $21^{\text {st }}$ century. ${ }^{4}$ It is therefore of utmost importance to limit $\mathrm{N}_{2} \mathrm{O}$ production and find efficient ways to reduce $\mathrm{N}_{2} \mathrm{O}$ into $\mathrm{N}_{2} . \mathrm{N}_{2} \mathrm{O}$ is thermodynamically a good oxidant ${ }^{5}$ but a kinetically inert molecule. Its reduction resorts to small molecule activation via catalysis and can be viewed as a prototypical N-O bond activation process. Three enzymes have been reported to be able to reduce nitrous oxide, namely $\mathrm{N}_{2} \mathrm{O}$ reductase enzymes. ${ }^{6}$ Catalysis of the reduction of $\mathrm{N}_{2} \mathrm{O}$ can be performed using metal electrodes such as palladium, platinum, indium or iridium. However those metals are rare and expensive and the use of abundant metals suffers selectivity issues (competition with hydrogen evolution). ${ }^{7,8} \mathrm{We}$ thus turn to molecular catalysis where substrate, products, catalysts and intermediates belong to the molecular world. In that regards, numerous advances have been made in recent years in understanding the activation of $\mathrm{C}-\mathrm{O},{ }^{9} \mathrm{O}-\mathrm{O}^{10}$ or $\mathrm{P}-\mathrm{O}^{11}$ bonds using molecular electrochemistry tools. ${ }^{12,13}$ Much less is known regarding $\mathrm{N}-\mathrm{O}$ bond. Although binding and activation of $\mathrm{N}_{2} \mathrm{O}$ at transition metal centers has been studied and reviewed, ${ }^{14,15}$ there have been relatively few attempts to use, as molecular catalysts, low-valent transition metal complexes. Cofacial cobalt porphyrins have been shown to be active, albeit at moderate rates. ${ }^{16}$ Studies in aqueous medium have been carried out with nickel complexes on mercury electrode, ${ }^{17}$ but, as in the case of $\mathrm{CO}_{2}$ reduction with nickel cyclams,${ }^{18}$ mercury seems to be playing a role in the process. When adsorbed on the surface of a graphite electrode, it has been shown that cobalt (II) tetraaminophthalocyanine behaves like a molecular catalyst reducing $\mathrm{N}_{2} \mathrm{O}$ to $\mathrm{N}_{2}$ in aqueous medium, but the proposed mechanistic analysis presents some inconsistencies and deserves to be deepened in order to better define the factors controlling the activation of the $\mathrm{N}-\mathrm{O}$ bond. ${ }^{19}$

$\mathrm{N}_{2} \mathrm{O}$ presents analogies to $\mathrm{CO}_{2}$ : the two molecules are isoelectronic, they have a central electrophilic atom and their reduction with two electrons leads to the rupture of an $\mathrm{N}-\mathrm{O}$ or $\mathrm{C}-\mathrm{O}$ bond and to the stabilization of the oxygen atom with two protons. Therefore, we reasoned that the principles at play for $\mathrm{CO}_{2}$ to $\mathrm{CO}$ conversion with rhenium bipyridyl carbonyl complexes ${ }^{20}$ could be a source of inspiration for $\mathrm{N}_{2} \mathrm{O}$ to $\mathrm{N}_{2}$ transformation. a

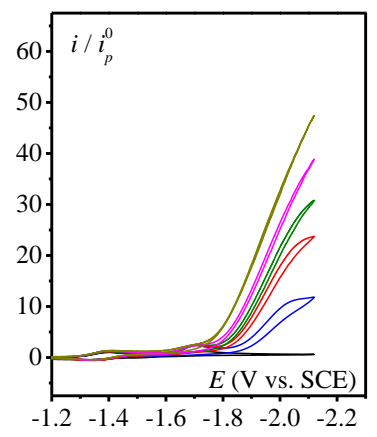

b

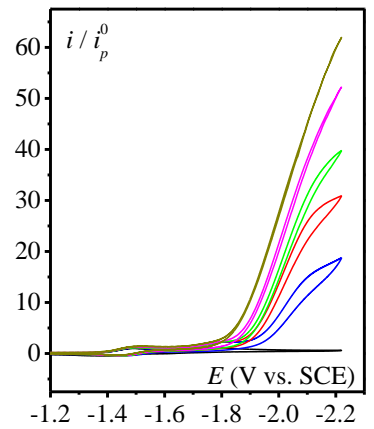

Figure 1. $\mathrm{CVs}$ of (a) $\left[\mathrm{Re}(\mathrm{bpy})(\mathrm{CO})_{3} \mathrm{Cl}\right] \quad(1 \mathrm{mM})$ and (b) $\left[\mathrm{Re}(\mathrm{dmbpy})(\mathrm{CO})_{3} \mathrm{Cl}\right](1 \mathrm{mM})$, in acetonitrile with $n-\mathrm{Bu}_{4} \mathrm{NPF}_{6}(0.1$ $\mathrm{M})$ on a $3 \mathrm{~mm}$ diameter glassy carbon electrode. $v=0.1 \mathrm{~V} / \mathrm{s}$. Under argon (black). Under $1 \mathrm{~atm} \mathrm{~N}_{2} \mathrm{O}$ (blue) and with increasing amount of water: 0.1 (red), 0.2 (green), 0.5 (magenta), 1 (dark yellow) M. $i_{p}^{0}=0.446 F S C_{\text {cat }}^{0} \sqrt{D F v / R T} . S$ is the electrode surface area, $C_{\text {cat }}^{0}$ is the catalyst concentration, $D$ the catalyst diffusion coefficient, $F$ the Faraday, $R$ the gas constant, $T$ the temperature. 
We have found that $\left[\operatorname{Re}(\mathrm{L})(\mathrm{CO})_{3} \mathrm{Cl}\right]$ metal $\left(\mathrm{L}=2,2^{\prime}\right.$ bipyridine (bpy) and 4,4'-dimethyl-2,2'-bipyridine (dmbpy)) exhibit efficient, selective and stable catalytic activity for reducing $\mathrm{N}_{2} \mathrm{O}$ to $\mathrm{N}_{2}$ in the presence of water. Figure 1 shows the catalytic currents observed in cyclic voltammetry $(\mathrm{CV})$ with $\left[\mathrm{Re}(\mathrm{L})(\mathrm{CO})_{3} \mathrm{Cl}\right]$ in $\mathrm{CH}_{3} \mathrm{CN}$ electrolyte in the presence of $\mathrm{N}_{2} \mathrm{O}$ and increasing amount of water. In the absence of $\mathrm{N}_{2} \mathrm{O}$, the catalysts exhibit the classical behavior reported for such complexes (Figure S2). ${ }^{20,21} \mathrm{~A}$ first one electron reversible reduction of the bipyridine ligand is observed. It is followed by a second reduction coupled to the chloride ligand decoordination. This second reduction is in competition with spontaneous dehalogenation of the bpy centered monoreduced species which can dimerize to form a metal bonded Re-Re dimer. ${ }^{21}$ Therefore the stoichiometry of the second wave is less than one electron (see Supporting Information (SI) for simulations). Depending on the dryness of the solvent and supporting electrolyte, a third reduction wave corresponding to the dimer reduction can be observed at more negative potential (Figure S3). Upon saturation of the solution with $\mathrm{N}_{2} \mathrm{O}$, the first reduction wave remains unchanged but the second wave grows to reach a one electron stoichiometry (Figure S4). A new large wave appears at more negative potential (Figure 1). Control experiment shows that no such wave is observed in the absence of catalyst; the direct reduction of $\mathrm{N}_{2} \mathrm{O}$ at the glassy carbon electrode occurs at more negative potential indicating that the overpotential has been reduced by ca. $500 \mathrm{mV}$ (Figure S5). The catalytic wave exhibits the characteristic canonical S-shape of a fast catalytic process in the presence of excess of substrate. The steadystate nature of the catalytic current is confirmed by its invariance with scan rate (Figure S6). Interestingly we observed an increase of the catalytic current upon addition of water (Figure 1). As expected, $\left[\operatorname{Re}(d m b p y)(\mathrm{CO})_{3} \mathrm{Cl}\right]$ is reduced at more negative potential than $\left[\operatorname{Re}(b p y)(\mathrm{CO})_{3} \mathrm{Cl}\right]$ due to the electronic donating effect of the methyl substituent. We observed that the catalytic wave is at more negative potential with $\left[\mathrm{Re}(\mathrm{dmbpy})(\mathrm{CO})_{3} \mathrm{Cl}\right]$ than with $\left[\mathrm{Re}(\mathrm{bpy})(\mathrm{CO})_{3} \mathrm{Cl}\right]$ but more intense with the former compared to the latter (in similar conditions).

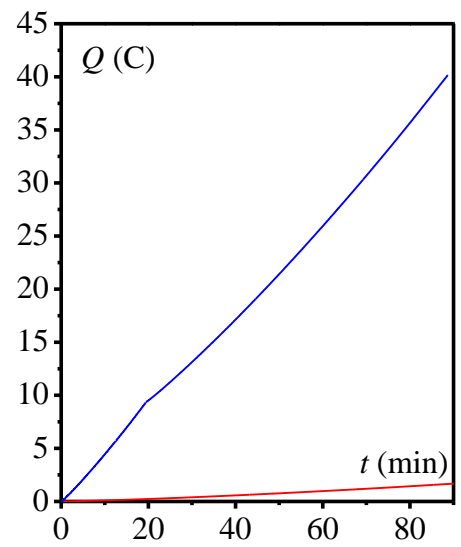

Figure 2. Controlled potential electrolysis at $-1.72 \mathrm{~V}$ vs. SCE of a solution of $\mathrm{CH}_{3} \mathrm{CN} / \mathrm{H}_{2} \mathrm{O}(90 / 10)+0.1 \mathrm{M} \mathrm{NBu}_{4} \mathrm{PF}_{6}$ with $\left[\operatorname{Re}(\right.$ bpy $\left.)(\mathrm{CO})_{3} \mathrm{Cl}\right](0.5 \mathrm{mM})$ under 1 atm of $\mathrm{N}_{2} \mathrm{O}$ on a $1 \mathrm{~cm}^{2}$ glassy carbon electrode. Charge passed as function of time in the presence of catalyst (blue) and in the absence of catalyst (red).

Controlled potential electrolysis was performed at $-1.72 \mathrm{~V}$ vs. SCE in a solution containing $1 \mathrm{mM}$ of $\left[\mathrm{Re}(\mathrm{bpy})(\mathrm{CO})_{3} \mathrm{Cl}\right]$ in a $\mathrm{CH}_{3} \mathrm{CN} / \mathrm{H}_{2} \mathrm{O}(90 / 10)$ mixture under $\mathrm{N}_{2} \mathrm{O}$ atmosphere. A stable current density of ca. $7.5 \mathrm{~mA} / \mathrm{cm}^{2}$ was measured for 90 min leading to a linear increase of the charge passed over time (Figure 2). Gas chromatography analysis of the gas headspace allows determination of the quantity of $\mathrm{N}_{2}$ produced after passage of 20,33.5 and $40 \mathrm{C}$ (see SI for details of calculation) indicating a selective transformation of $\mathrm{N}_{2} \mathrm{O}$ to $\mathrm{N}_{2}$ according to:

$$
\mathrm{N}_{2} \mathrm{O}+2 \mathrm{e}+2 \mathrm{H}_{2} \mathrm{O} \rightarrow \mathrm{N}_{2}+2 \mathrm{OH}^{-}
$$

No $\mathrm{H}_{2}$ was detected. $\mathrm{CVs}$ run before electrolysis and passage of $40 \mathrm{C}$ shows no significant degradation of the catalyst (see Figure S1). Control experiment at constant potential in the absence of catalyst confirm the absence of $\mathrm{N}_{2} \mathrm{O}$ reduction at $-1.72 \mathrm{~V}$ vs. SCE (Figure 2).

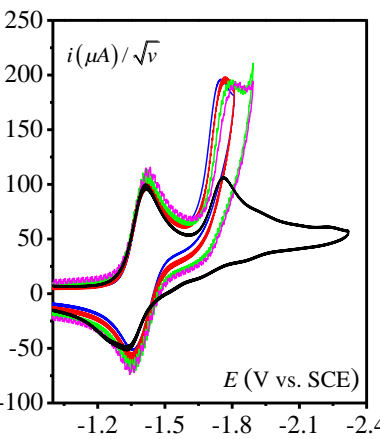

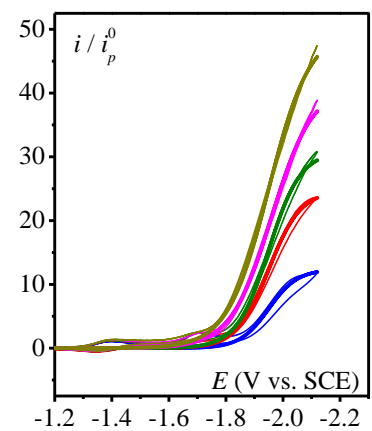

Figure 3. (a) $\mathrm{CVs}$ of $\left[\mathrm{Re}(\mathrm{bpy})(\mathrm{CO})_{3} \mathrm{Cl}\right](1 \mathrm{mM})$ under argon (black) and under 1 atm $\mathrm{N}_{2} \mathrm{O}$ at $v=0.1$ (blue), 0.2 (red), 0.5 (green), 1 (magenta) V/s. (b) $\mathrm{CVs}$ of $\left[\operatorname{Re}(\right.$ bpy $\left.)(\mathrm{CO})_{3} \mathrm{Cl}\right](1 \mathrm{mM})$ under 1 atm $\mathrm{N}_{2} \mathrm{O}$ (blue) and with increasing amount of water: 0.1 (red), 0.2 (green), 0.5 (magenta), 1 (dark yellow) M. $v=0.1 \mathrm{~V} / \mathrm{s}$. Thick lines correspond to simulations according to equation (4). Solvent: acetonitrile with $n-\mathrm{Bu}_{4} \mathrm{NPF}_{6}(0.1 \mathrm{M}) .3 \mathrm{~mm}$ diameter glassy carbon electrode.

Analysis of the $\mathrm{CVs}$ provides insights into the mechanism. We focus on $\left[\operatorname{Re}(b p y)(\mathrm{CO})_{3} \mathrm{Cl}\right]$ catalyst noting that the same features are observed with $\left[\operatorname{Re}(\operatorname{dmbpy})(\mathrm{CO})_{3} \mathrm{Cl}\right]$. As already mentioned, in the presence of $\mathrm{N}_{2} \mathrm{O}$ the first reduction wave of the catalyst remains unchanged indicating the storage of an electron on the bipyridine ligand, i.e. formation of $\left[\mathrm{Re}\left(\mathrm{bpy}^{\bullet-}\right)(\mathrm{CO})_{3} \mathrm{Cl}\right]^{-}$. The second wave, which stoichiometry is below one electron under argon due to partial formation of the dimer reaches a one electron stoichiometry under $\mathrm{N}_{2} \mathrm{O}$ (Figure 3a). This suggests a fast addition of $\mathrm{N}_{2} \mathrm{O}$ on the intermediate driving the reaction to the formation of $\left[\operatorname{Re}^{0}\left(\text { bpy }^{\bullet-}\right)(\mathrm{CO})_{3}\left(\mathrm{~N}_{2} \mathrm{O}\right)\right]^{-}$(Note that we do not speculate on the type of binding of $\mathrm{N}_{2} \mathrm{O}$ on $\mathrm{Re}$ ) and preventing formation of the dimer. However the wave does not shift significantly upon addition of $\mathrm{N}_{2} \mathrm{O}$ indicating that $\mathrm{N}_{2} \mathrm{O}$ binding occurs once $\left[\mathrm{Re}\left(\mathrm{bpy}^{\bullet-}\right)(\mathrm{CO})_{3} \mathrm{Cl}\right]^{-}$has been reductively dechlorinated thus creating a labile position on the reduced metal ready to binds $\mathrm{N}_{2} \mathrm{O}$. We also note that this second wave is not shifting significantly upon addition of water (Figure S7). Hence we propose that addition of water is not influencing the binding of $\mathrm{N}_{2} \mathrm{O}$ on $\left[\operatorname{Re}^{0}\left(\text { bpy }^{--}\right)(\mathrm{CO})_{3}\right]^{-}$. The catalytic process is triggered at more negative potential, suggesting that it is initiated by $\left[\mathrm{Re}\left(\text { bpy }^{\bullet-}\right)(\mathrm{CO})_{3}\left(\mathrm{~N}_{2} \mathrm{O}\right)\right]^{-}$reduction. This electrode electron transfer is slow and rate determining in the rising part of the catalytic wave as revealed by a sluggish rise of the current despite careful ohmic drop compensation. At large overpotential, a plateau current is reached indicating kinetic limitation by a chemical event. This chemical event involves water as co-substrate as the plateau current is increasing upon addition of water (Figure 1 and $3 \mathrm{~b}$ ). It can be proposed that the chemical event is a series of steps leading to (i) N-O bond 
cleavage boosted by the presence of a proton donor $\left(\mathrm{H}_{2} \mathrm{O}\right)$ and (ii) $\mathrm{N}_{2}$ release. The resulting intermediate, $\left[\operatorname{Re}^{\mathrm{I}}\left(\mathrm{bpy}^{\bullet-}\right)(\mathrm{CO})_{3}\right]$, is likely reduced at the applied potential and then binds another $\mathrm{N}_{2} \mathrm{O}$ molecule thus closing the catalytic loop. The proposed mechanism is summarized on Scheme 1.

Scheme 1. Proposed mechanism for $\mathrm{N}_{2} \mathrm{O}$ reduction.

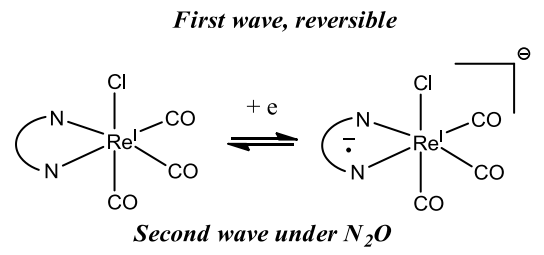

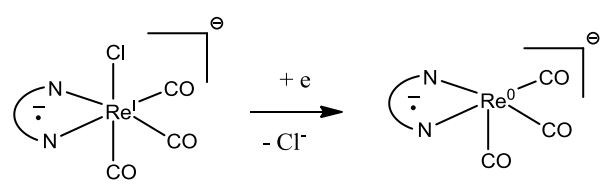

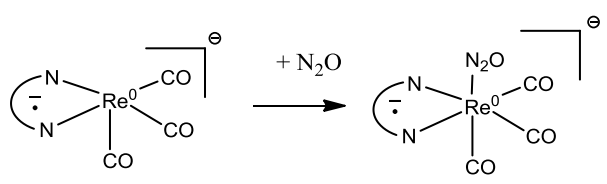

Third wave under $\mathrm{N}_{2} \mathrm{O}$ : catalytic process

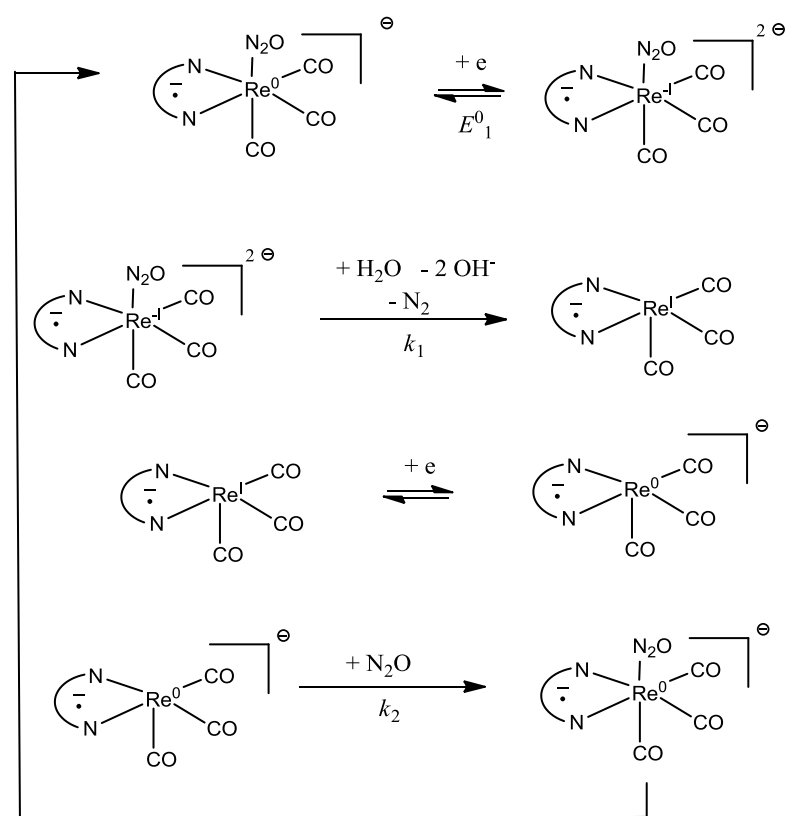

An apparent rate constant for the overall process, $k_{a p}\left(\mathrm{~s}^{-1}\right)$, can be obtained from the plateau current assuming that the thermodynamically downhill electron transfer occurs homogeneously rather than at the electrode surface (see SI):

$$
\frac{i_{p l}}{i_{p}^{0}}=2.24 \sqrt{\frac{R T}{F v}} \sqrt{2 k_{a p}}
$$

$$
k_{a p}=\frac{k_{1}}{\left(1+\frac{\sqrt{k_{1} / k_{2}}}{\sqrt{2}+\sqrt{k_{2} / k_{1}}}\right)^{2}}
$$

where $k_{1}$ and $k_{2}$ are the apparent rate constant for the two chemical irreversible sequences of the catalytic loop shown on scheme 1 .
The variation of $k_{a p}$ with water concentration reported for both catalysts in Figure 4 shows a beneficial role of water on the chemical process characterized by $k_{1}$. Fitting of $k_{a p}$ vs. $\left[\mathrm{H}_{2} \mathrm{O}\right]$ using equation (3) and considering $k_{1}=k_{1,0}+k_{1,1}\left[\mathrm{H}_{2} \mathrm{O}\right]$ and $k_{2}$ independant of $\left[\mathrm{H}_{2} \mathrm{O}\right]$ (vide supra) leads to the values gathered in Table 1. Note that this allows to estimate the maximal turnover frequency $T O F_{\text {max }}=k_{1} k_{2} /\left(k_{1}+k_{2}\right)$ for any water content (for example, for $\left[\operatorname{Re}(b p y)(C O)_{3} \mathrm{Cl}\right], T O F_{\max }=58.5 \mathrm{~s}^{-1}$ in absence of water and $T O F_{\max }=1080 \mathrm{~s}^{-1}$ with $\left.1 \mathrm{M} \mathrm{H}_{2} \mathrm{O}\right)$. The rate constant are larger with $\left[\mathrm{Re}(\mathrm{dmbpy})(\mathrm{CO})_{3} \mathrm{Cl}\right]$ than with $\left[\mathrm{Re}(\mathrm{bpy})(\mathrm{CO})_{3} \mathrm{Cl}\right]$, in line with the more donating electronic effect of dmbpy compared to bpy. Note also that the apparent rate constants for both $\left[\mathrm{Re}(\mathrm{dmbpy})(\mathrm{CO})_{3} \mathrm{Cl}\right]$ and $\left[\mathrm{Re}(\mathrm{bpy})(\mathrm{CO})_{3} \mathrm{Cl}\right]$ are much larger than the rate constants reported for cobalt porphyrins in benzonitrile with $\mathrm{Bu}_{4} \mathrm{NOH}$ (of the order of $1 \mathrm{~s}$ $\left.{ }^{1}\right){ }^{16}$

Table 1. Rate constants

\begin{tabular}{|l|c|c|c|}
\hline catalyst & $k_{1,0}\left(\mathrm{~s}^{-1}\right)$ & $k_{1,1}\left(\mathrm{M}^{-1} \mathrm{~s}^{-1}\right)$ & $k_{2}\left(\mathrm{~s}^{-1}\right)$ \\
\hline$\left[\operatorname{Re}(\mathrm{bpy})(\mathrm{CO})_{3} \mathrm{Cl}\right]$ & 60 & 1900 & 2400 \\
\hline$\left[\operatorname{Re}(\right.$ dmbpy $\left.)(\mathrm{CO})_{3} \mathrm{Cl}\right]$ & 141 & 2600 & 8000 \\
\hline
\end{tabular}

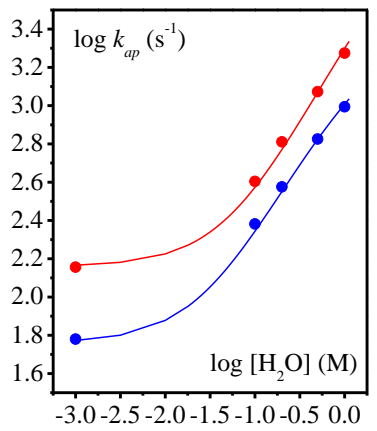

Figure 4. Apparent rate constant as function of added water obtained from equation (2) for the reduction of $\mathrm{N}_{2} \mathrm{O}$ with $\left[\mathrm{Re}(\mathrm{bpy})(\mathrm{CO})_{3} \mathrm{Cl}\right]$ (blue) and $\left[\operatorname{Re}(\mathrm{dmbpy})(\mathrm{CO})_{3} \mathrm{Cl}\right]$ (red). The value in absence of water is arbitrarily plotted at $\log \left[\mathrm{H}_{2} \mathrm{O}\right]=-3$. Lines correspond to fitting with equation (3).

In the framework of the proposed reaction scheme, the catalytic wave in canonical conditions can be written as (see SI):

$$
\frac{i}{i_{p}^{0}} \approx \frac{i_{p l} / i_{p}^{0}}{1+\exp \left[\frac{\alpha F}{R T}\left(E-E_{a p}\right)\right]}
$$

with

$$
E_{a p}+\frac{R T}{\alpha F} \ln \left(\frac{i_{p l}}{i_{p}^{0}}\right)=E_{1}^{0}+\frac{R T}{\alpha F} \ln \left(\frac{k_{S}}{0.446 \sqrt{D F v / R T}}\right)
$$

where $E_{1}^{0}, k_{S}$ and $\alpha$ are respectively the standard potential, the standard rate constant and the transfer coefficient for the reduction of $\left[\operatorname{Re}^{0}\left(\mathrm{bpy}^{\bullet-}\right)(\mathrm{CO})_{3}\left(\mathrm{~N}_{2} \mathrm{O}\right)\right]^{-}$ identified as the potential limiting event. Fitting of the catalytic wave using equation (4) (Figure $3 b$ and Figure S8) leads to an evaluation of $E_{1}^{0}+\frac{R T}{\alpha F} \ln \left(\frac{k_{S}}{0.446 \sqrt{D F v / R T}}\right)$ for 
both catalysts as function of water concentration. It is remarkable that this quantity shifts anodically by $120 \mathrm{mV}$ per decade of $\log \left[\mathrm{H}_{2} \mathrm{O}\right]$ (Figure 5). Unfortunately it is not possible to separate the thermodynamic parameter $\left(E_{1}^{0}\right)$ from the kinetic parameter $\left(k_{S}\right)$ from our experiments. However, besides the increase of $k_{a p}$ (and $T O F_{\max }$ ), we reveal here an additional beneficial effect of water for $\mathrm{N}_{2} \mathrm{O}$ reduction, via stabilization of the reduced intermediate $\left[\mathrm{Re}^{-}\right.$ $\left.{ }^{\mathrm{I}}\left(\mathrm{bpy}^{-}{ }^{-}\right)(\mathrm{CO})_{3}\left(\mathrm{~N}_{2} \mathrm{O}\right)\right]^{2-}$ with two water molecules, leading to an anodic shift of $E_{1}^{0}$ by $120 \mathrm{mV}$ per decade of $\mathrm{H}_{2} \mathrm{O}$ concentration, or via an increase of the standard rate constant by one order of magnitude per decade of $\mathrm{H}_{2} \mathrm{O}$ concentration. This additional effect allows to reduce the potential to be applied to get a substantial current. The consistency of the whole analysis is checked by comparison of experimental data with numerical simulation of the catalytic wave using the extracted information (Figure S10).

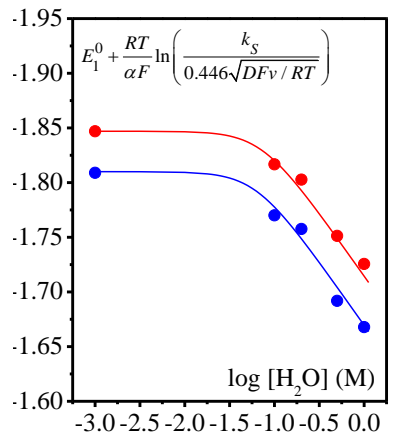

Figure 5. Plot of $E_{1}^{0}+\frac{R T}{\alpha F} \ln \left(\frac{k_{S}}{0.446 \sqrt{D F v / R T}}\right)$ as function of added water for $\left[\operatorname{Re}(\mathrm{bpy})(\mathrm{CO})_{3} \mathrm{Cl}\right]$ (blue) and $\left[\mathrm{Re}(\mathrm{dmbpy})(\mathrm{CO})_{3} \mathrm{Cl}\right]$ (red).

Finally, we would like to emphasize that development of non critical metal complexes as catalyts would be necessary. Preliminary results show that $\left[\mathrm{Mn}(\mathrm{bpy})(\mathrm{CO})_{3} \mathrm{Br}\right]$ and $\left[\mathrm{Mn}(\mathrm{dmbpy})(\mathrm{CO})_{3} \mathrm{Br}\right]^{22}$ are also active catalysts for $\mathrm{N}_{2} \mathrm{O}$ reduction (Figure $\mathrm{S} 11$ ) but less efficient in terms of $T O F_{\max }$ than the rhenium complexes reported here. We are currently developping new sustainable metallic complexes to go in such direction.

In conclusion, we have shown that rhenium bipyridyl carbonyl complexes are stable and selective catalysts for deoxygenation of $\mathrm{N}_{2} \mathrm{O}$ in the presence of water to form $\mathrm{N}_{2}$ inert gas. Proton donors such as water are clearly beneficial to enhance the catalytic chemical rate but also the electrochemical limiting event as revealed by analysis of CVs. Compared to the direct reduction of $\mathrm{N}_{2} \mathrm{O}$ on glassy carbon the overpotential is remarkably reduced by ca. $500 \mathrm{mV}$. There is however still plenty of room for improvement. These results should trigger further studies on electrochemical $\mathrm{N}-\mathrm{O}$ bond activation using molecular catalysts.

\section{ASSOCIATED CONTENT}

\section{AUTHOR INFORMATION}

\section{Corresponding Author}

cyrille.costentin@univ-grenoble-alpes.fr sylvie.chardon@univ-grenoble-alpes.fr

\section{Notes}

The authors declare no competing financial interest.

\section{Supporting Information}

Experimental details. Derivation of equations (2)-(5). Additional CVs. Digital simulations. Data with $\left[\mathrm{Mn}(\mathrm{bpy})(\mathrm{CO})_{3} \mathrm{Br}\right]$ and $\left[\mathrm{Mn}(\mathrm{dmbpy})(\mathrm{CO})_{3} \mathrm{Br}\right]$ catalysts.

\section{ACKNOWLEDGMENT}

The MITI (Mission pour les Initiatives Transverses et Interdisciplinaires) program of the CNRS is gratefully acknowledged for RD doctoral financial support. This work was partially supported by the Agence Nationale de la Recherche (Labex ARCANE, CBH-EUR-GS, ANR-17-EURE-0003). The NanoBio ICMG (UAR 2607), is acknowledged for providing facilities for NMR analyses.

\section{REFERENCES}

1. Lehnert, N.; Dong, H. T.; Harland, J. B.; Hunt, A. P.; White, C. J. Reversing Nitrogen Fixation. Nat. Rev. Chem. 2018, 2, 278-289

2. Mosier, A.; Syers, J. K.; Freney, J. R. Agriculture and the Nitrogen Cycle: Assessing the Impacts of Fertilizer Use on Food Production and the Environment. Island Press, 2013.

3. Solomon, S.; Qin, D.; Manning, M.; Chen, Z.; Marquis, M.; Averyt, K.; Tignor, M. M. B.; Miller, H. L. Contribution of Working Group I to the fourth Assessment report of the Intergovernmental Panel on climate Change, Cambridge University Press, Cambridge, UK, 2007.

4. Ravishankara, A. R.; Daniel, J. S.; Portmann, R. W. Nitrous Oxide $\left(\mathrm{N}_{2} \mathrm{O}\right)$ : The Dominant Ozone-Depleting Substance Emitted in the $21^{\text {st }}$ Century. Science 2009, 326, 123-125.

5. (a) Latimer, W. M. Oxidation Potentials, Prentice-Hall, New York, 1952, Chap. 7. (b) Groves, J. T.; Roman, J. S. Nitrous Oxide Activation by a Ruthenium Porphyrin. J. Am. Chem. Soc. 1995, 117, 5594-5595.

6. Pauleta, S. R.; Carepo, M. S. P. ; Moura, I. Source and Reduction of Nitrous Oxide. Coord. Chem. Rev. 2019, 387, 436-449.

7. Kudo, A.; Mine, A. Electrocatalysis for $\mathrm{N}_{2} \mathrm{O}$ reduction on metal electrodes. J. Electroanal. Chem. 1996, 408, 267-269.

8. Gomez, R.; Weaver, M. J. Reduction of Nitrous Oxide on Iridium Single-Crystal Electrodes. Langmuir 2002, 18, 44264432.

9. Francke, R.; Schille, B.; Roemelt, M. Homogeneously Catalyzed Electroreduction of Carbon Dioxide - Methods, Mechanisms, and Catalysts. Chem. Rev. 2018, 118, 4631-47016.

10. (a) Anxolabéhère-Mallart, E.; Banse, F. Bioinspired Molecular Catalysts for Homogenous Electrochemical Activation of Dioxygen. Curr. Opin. Electrochem. 2019, 15, 118-124. (b) Passard, G.; Dogutan, D. K.; Qiu, M.; Costentin, C.; Nocera, D. G. Proton coupled electron transfer bond cleavage of oxygen promoted by manganese porphyrins. ACS Catalysis 2018, 8, 8671-8679. (c) Dey, S.; Mondal, B.; Chatterjee, S.; Rana, A.; Amanullah, S.; Dey, A. Molecular Electrocatalysts for the Oxgen Reduction Reaction. Nat. Rev. Chem. 2017, 0098.

11. Elias, J. S.; Costentin, C.; Nocera, D. G. Direct electrochemical $\mathrm{P}(\mathrm{V})$ to $\mathrm{P}(\mathrm{III})$ reduction of phosphine oxide facilitated by triaryl borates. J. Am. Chem. Soc. 2018, 140, 1371113718. 
12. Costentin, C.; Savéant, J-M. Multi-electron multi-step molecular catalysis of electrochemical reactions. Benchmarking of homogeneous catalysts. ChemElectroChem. 2014, 1, 1226-1236.

13. Costentin, C., Nocera, D. G., Brodsky, C. N. Multielectron, Multi-substrate Homogeneous Molecular Catalysis of Electrochemical Reactions: Kinetic Analysis in the Total Catalysis Regime. Proc. Natl. Acad. Sci. USA 2017, 114, 11303-11308.

14. Tolman, W. B. Binding and Activation of $\mathrm{N}_{2} \mathrm{O}$ at Transition-Metal Centers: Recent Mechanistic Insights. Angew. Chem. Int. Ed. 2010, 49, 1018-1024.

15. Severin, K. Synthetic Chemistry with Nitrous Oxide. Chem. Soc. Rev. 2015, 44, 6375-6386.

16. Collman, J. P.; Marrocco, M.; Elliott, C. M.; L'Her, M. Electrocatalysis of nitrous oxide reduction. Comparison of several porphyrins and binary "face-to-face" porphyrins. $J$. Electroanal Chem. 1981, 124, 113-131.

17. Taniguchi, I.; Shimpuku, T.; Yamashita, K.; Ohtaki, H. Electrocatalytic Reduction of Nitrous Oxide to Dinitrogen at a Mercury Electrode using Ni ${ }^{\text {II }}$ Complexes of Macrocyclic Polyamines. J. Chem. Soc., Chem. Commun.. 1990, 915-917.

18. Beley, M.; Collin, J-P.; Ruppert, R.; Sauvage, J-P. Nickel(II)-cyclam: an extremely selective electrocatalyst for reduction of $\mathrm{CO}_{2}$ in water. J. Chem. Soc., Chem. Commun. 1984, $1315-1316$.

19. Zhang, J.; Tse, Y-H.; Lever, A. B. P. ; Pietro, W. J. Electrochemical Reduction of Nitrous Oxide $\left(\mathrm{N}_{2} \mathrm{O}\right)$ catalyzed by Tetraaminophthalocynatocobalt(II) Adsorbed on a Graphite Electrode in Aqueous Solution. J. Porphyrins Phtalocyanines 1997, $1,323-331$.

20. Sullivan, B. P.; Bolinger, C. M; Conrad, D.; Vining, W. J.; Meyer, T. J. One- and Two-electron Pathways in the Electrocatalytic Reduction of $\mathrm{CO}_{2}$ by $f a c-\operatorname{Re}($ bpy $)(\mathrm{CO})_{3} \mathrm{Cl}$ (bpy $=2,2$ '-bipyridine) J. Chem. Soc., Chem. Commun. 1985, 1414-1416.

21. (a) Stor, G. J.; Hartl, F.; van Outerstep, J. W. M.; Stufkens, D. J. Spectroelectrochemical (IR, UV/Vis) Determination of the Reduction Pathways for a Series of $\left[\operatorname{Re}(\mathrm{CO})_{3}(\alpha-\right.$ diimine $\left.) \mathrm{L}^{\prime}\right]^{0 /+}\left(\mathrm{L}^{\prime}=\right.$ Halide, Otf ${ }^{-}, \mathrm{THF}, \mathrm{MeCN}, n-\mathrm{PrCN}, \mathrm{PPh}_{3}$, $\left.\mathrm{P}(\mathrm{OMe})_{3}\right)$ Complexes. Organometallics 1995, 14, 1115-1131. (b) Paolucci, F.; Marcaccio, M.; Paradisi, C.; Roffia, S.; Bignozzi, C. A. ; Amatore, C. Dynamics of the Electrochemical Behavior of Diimine Tricarbonyl Rhenium(I) Complexes in Strictly Aprotic Media. J. Phys. Chem. B 1998, 102, 47594769. (c) Machan, C. W.; Sampson, M. D.; Chabolla, S. A.; Dang, T.; Kubiak, C. P. Developing a Mechanistic Understanding of Molecular Electrocatalysts for $\mathrm{CO}_{2}$ Reduction using Infrared Spectroelectrochemistry. Organometallics 2014, 33, 4550-4559.

22. (a) $\left[\mathrm{Mn}(\mathrm{bpy})(\mathrm{CO})_{3} \mathrm{Br}\right]$ is known as an efficient catalyst for $\mathrm{CO}_{2}$ to $\mathrm{CO}$ conversion in a $\mathrm{CH}_{3} \mathrm{CN} / \mathrm{H}_{2} \mathrm{O}$ solvent mixture. (b) Bourrez, M.; Molton, F.; Chardon-Noblat, S.; Deronzier, A. $\left[\mathrm{Mn}\right.$ (bipyridyl) $\left.(\mathrm{CO})_{3} \mathrm{Br}\right]$ : An Abundant Metal Carbonyl Complex as Efficient Electrocatalyst for $\mathrm{CO}_{2}$ Reduction. Angew. Chem. Int. Ed. 2011, 50, 9903-9906. 